Universities Council on Water Resources

Journal of Contemporary Water Research \& Education

Issue 134, PAges 19-22, July 2006

\title{
Geomorphology and Restoration Ecology
}

\author{
David R. Montgomery \\ Quaternary Research Center and Department of Earth \& Space Sciences \\ University of Washington
}

$\mathrm{H}$ ow can geomorphologists best contribute to the emerging field of restoration ecology? I have struggled with this question over the past decade working to understand the role of habitat change on the evolution and recent decline of salmon. Based on experiences participating in, thinking about, and observing watershed restoration efforts, I have come to believe that taking full advantage of the potential for geomorphology to contribute to restoration ecology requires conceptual and educational shifts to better integrate historical and process-oriented perspectives into professional practice.

Obviously, restoration ecology involves addressing a lot more than the simple sum of the individual influences of the physical environment, if only because of interactions among organisms. Nevertheless, fundamental environmental conditions and processes influenced or controlled by geology, hydrology, and geomorphology all illustrate the need for integrating both historical and process-oriented perspectives in the practice of restoration ecology. While insights from the earth sciences, as well as ecology and engineering, are essential for designing river restoration measures intended to benefit aquatic ecosystems and endangered species, no standards of practice or professional qualifications currently exist. Academic training of practitioners is quite varied; students graduating from the University of Washington to work in river restoration come from landscape architecture, forestry, fisheries, civil engineering, and the geosciences. I have met a comparably wide range of practicing professionals selling their expertise as river restorationists. Once, in the field at a restoration project site, a consultant handed me a card that identified him as a "fluvial geomorphologist." When I asked where he had done his graduate work, he informed me that he had a bachelor's degree in forestry, and no formal training in fluvial geomorphology. This did not seem to bother him, even though the fate of salmon in the Pacific Northwest is increasingly tied to the success of river restoration efforts.

Although a large sum of money is being spent to restore rivers and salmon in the continental U.S., many projects fail due to reliance on "offthe-shelf" concepts and designs instead of sitespecific understanding of the disturbance history, habitat conditions, and habitat-forming processes in individual rivers. Recognition that contextdependent physical and biological processes mediate the cascade of linkages between geology, hydrology, geomorphology, and salmon ecology should provide the foundation for societies' efforts to restore robust salmon populations. Recognizing the specific local relevance of general theory is central to the effective scoping, conceptualization, and design of river restoration projects. Such insight requires rigorous, yet broad-based training.

Salmon recovery efforts require an interdisciplinary approach to restoration ecology due to the historical effects of changes in geomorphologic processes and disturbance regimes on salmon populations. It has been recognized for centuries that the health of salmon runs depends on the condition of their home streams. Experience in managing salmon in Europe and New England (Montgomery 2003), as well as recent landscape-level research in the Pacific Northwest (Montgomery et al. 1999, Rosenfeld et al., 2000, Pess et al. 2002), has shown that the processes that shape riverine habitat lead to strong associations between salmon populations and habitat availability, characteristics, and quality. It now appears self- 
evident that salmon recovery efforts should be rooted in understanding of both hydro-geomorphic processes and historical changes to rivers and streams.

Centuries ago, rivers across northern Europe were full of salmon. Until the 1700 s, thousands of salmon were taken each day during spawning runs on French rivers. By the mid-1800s, continental stocks were so depleted that the French government instituted an aggressive (though ultimately futile) hatchery-based restoration program. Up to a quarter of a million salmon were caught from the Rhine each year before industrial pollution killed the river. By 1960, salmon were extinct in Germany, Belgium, Netherlands, and Switzerland. Today, salmon have been all but exterminated from continental Europe's once teeming salmon rivers.

Across the English Channel, attempts to recover and restore salmon date at least as far back as Queen Anne's 1712 act restricting salmon fishing on the Thames River. Shortly after Anne's death, George I enacted a law renewing stiff fines for blocking salmon from their spawning grounds in seventeen English rivers. Sadly, the Thames River salmon were among the first to disappear altogether in the 1830s. The story of the Thames played out all over the British Isles as salmon caught in the countryside flowed into the cities, while dams and habitat degradation shut salmon out of one river after another. By 1868, salmon could reach and survive in little more than a third of the area drained by England's salmon rivers.

Meanwhile, across the Atlantic Ocean, an explosive growth in small dams to power mills began to block salmon from their spawning grounds in prosperous New England colonies. Concern over preservation of the river fisheries motivated the colonial legislature to enact in 1709 the first of many laws to protect salmon, which forbade the construction of obstructions to fish passage. It also granted counties the power to regulate fishing for the public good, as well as to dismantle existing fish passage blockages. Despite many laws intended to protect salmon, even Maine's legendary salmon runs were in serious trouble by the start of the 20th century when more than 90 percent of the productive capacity of the state's salmon rivers had been lost to blockages from dams. New England's last few thousand wild Atlantic salmon are now listed under the Endangered Species Act, as are some of their western cousins.
The Pacific salmon are gone from a third of the area they inhabited just 150 years ago in California and the Pacific Northwest (Nehlsen et al. 1991). In 1991, one-third of Pacific salmon stocks in the continental U.S. were already extinct and half of all surviving stocks faced a high risk of extinction. Less than one out of six of the original Pacific salmon stocks remain in good shape-neither extinct nor at significant risk of extinction-in Washington, Oregon, Idaho, and California.

Despite these parallel stories of decline, it has been common knowledge for centuries that the salmon's life cycle involves residing in freshwater as juveniles before migrating to and from the sea and then returning to their native stream to spawn and die. This characteristic life history makes their abundance strongly dependent on the condition and disturbance history of their home stream and its watershed, as was known to people dependent upon salmon. Ancient Scottish and English laws regulating fishing on spawning grounds and providing for fish passage were founded upon a basic understanding of salmon life history. Today, the success of salmon recovery and habitat restoration efforts that cost millions of public and private dollars each year still depends on understanding the role of landscape processes and change on the ability of river systems to support salmon.

Salmon runs need habitat suitable for spawning, to foster the development of their eggs while buried in streambed gravel, and to shelter their young while they grow, forage, and hide from predators on their run down to the sea. Returning upriver, adults need deep, sheltered pools to rest, as well as clean gravel to spawn in. Recent studies of the forces shaping the rivers and mountains of the Pacific Northwest (e.g., Abbe and Montgomery 1996, 2003, Collins and Montgomery 2001, Collins et al. 2002, 2003,) indicate that the evolution and near extinction of salmon is in great part a story of changing landscapes (Montgomery 2000, 2003). Studies of forest channels in general and the historical ecology of Pacific Northwest rivers in particular have documented some of the changes in geomorphologic processes and disturbance regimes on salmon populations (Beechie et al. 1984; Montgomery et al. 1999, Collins et al. 2002).

At the simplest level, salmon habitat is influenced by landscape processes that govern the supply and movement of water, sediment, and wood to and 
through their rivers and streams. However, the relative and absolute importance of the specific watershed and fluvial processes that create, sustain, and destroy salmon habitat in particular rivers or streams depends on the regional and local differences in geology, hydrology, geomorphology, and the disturbance history of specific watersheds. Consequently, developing strategies for restoring salmon requires ascertaining what particular rivers were like before modern disturbances, how salmon habitat and habitat-forming processes changed, and what opportunities exist (or can be made) for reversing these changes.

Too often, however, river and stream restoration projects are based on ideas or technologies transferred from different geomorphologic contexts and applied in inappropriate situations due to inadequate understanding or appreciation for differences between regions and the history of particular places. An understanding of how specific changes in fluvial and watershed processes influence salmon habitat, as well as salmon themselves, is necessary to confidently align restoration efforts with policy goals. In addressing natural systems characterized by high uncertainty or large natural variability, an understanding of both past system behavior and the processes that govern that behavior are necessary to guide confident management and restoration.

Although in simple cases such as removing or modifying salmon-blocking culverts or dams, the solution may be obvious, in many cases, the diagnosis of restoration issues and design of projects to address them are complex and subjective. Integrating the linked influences of hydro-geomorphological and biological processes often requires synthetic thinking and analyses beyond solving a simple set of closed equations or adopting a standard design or conceptual model. In the real world, one-size-fits-all approaches -whether channel classifications or restoration guidelines - are of limited utility when applied without adequate understanding of both disturbance history and spatial context within a watershed.

In practice, however, many habitat restoration projects are based on standardized approaches and designs or the application of simple generalized conceptual models for what a stream should be like (Kondolf et al. 2003). Geomorphologists can contribute to restoration ecology by bringing technical expertise to bear on specific design problems. An essential contribution lies in an appreciation of context in the development of sitespecific understanding of habitat conditions and habitat-forming processes.

A common theme in the story of salmon runs in Europe, New England, and the Pacific Northwest is that changes in the physical structure and dynamics of river systems devastated salmon populations that had evolved under natural disturbance regimes (Montgomery 2003). How can we adapt our behavior to accommodate the processes that create, shape, and maintain salmon habitat, yet still accommodate the needs and economic desires of a growing human population? How can we increase salmon abundance in the face of projected increases in human population in this new century? These are really questions of applied landscape design - questions of applied geomorphology.

Without a solid foundation or basis in how rivers and the land formerly shaped salmon habitat - and thereby salmon populations - even the most wellintentioned social adaptations may fail or become so compromised as to be inefficient at best and ineffective at worst. If we are to recover salmon to more than a shadow of their former populations, an understanding of how historical changes to rivers and the geology of salmon needs to guide and inform difficult and controversial policy choices.

The challenge this presents suggests the need to adapt our educational system. In the medical and engineering professions, society has decided that obtaining expertise adequate for professional practice requires appropriate graduate-level study. The same should be true for river restoration.

But it is not. At present, almost anyone can claim adequate expertise to "restore" a river because there is no standard against which to judge qualifications. Many agencies rely on short courses to substitute for experience. In addition to the need to recognize the need for mandating appropriate expertise, there is the issue of how to train future professionals in graduate programs, and the question of what such programs should include. I believe that training in engineering hydrology, aquatic ecology, and fluvial geomorphology need to be integrated in coordinated programs aimed at merging professional level understanding of the fundamentals with practical experience in real contexts and situations. Salmon recovery in particular, and river restoration in general, depend on providing the right training to professionals engaged in the practice of restoration 
ecology. Development of interdisciplinary graduate programs in river restoration is an idea whose time has come. It is time that we started setting them up in our academic system, despite institutional obstacles to interdisciplinary programs.

\section{Author Bio and Contact Information}

DAVID R. Montgomery is the Director of the Quaternary Research Center at the University of Washington and author of King of Fish: The Thousand-Year Run of Salmon and the forthcoming Dirt: The Erosion of Civilizations. Contact information:dave@ess.washington.edu.

\section{References}

Abbe, T. B., and D. R. Montgomery. 1996. Interaction of large woody debris, channel hydraulics and habitat formation in large rivers. Regulated Rivers: Research \& Management 12: 201-221.

Abbe, T. B., and D. R. Montgomery. 2003. Patterns and process of wood debris accumulation in forest channels. Geomorphology 51: 81-107.

Beechie, T. J., E. Beamer, and L. Wasserman. 1994. Estimating coho salmon rearing habitat and smolt production losses in a large river basin and implications for restoration. North American Journal of Fisheries Management 14: 797-811.

Collins, B. D., and Montgomery, D. R. 2001. Importance of archival and process studies to characterizing pre-settlement riverine geomorphic processes and habitat in the Puget Lowland. Pages 227-243 in J. B. Dorava, D. R. Montgomery, B. Palcsak, and F. Fitzpatrick (eds.) Geomorphic Processes and Riverine Habitat. American Geophysical Union, Washington, DC.

Collins, B. D., D. R. Montgomery, and A. Haas. 2002. Historic changes in the distribution and functions of large woody debris in Puget Lowland rivers. Canadian Journal of Fisheries and Aquatic Sciences 59: 66-76.

Collins, B. D., D. R. Montgomery, and A. J. Sheikh. 2003. Reconstructing the historic riverine landscape of the Puget Lowland. Pages 79-128 in D. R. Montgomery, S. Bolton, D. B. Booth, and L. Wall (eds.). Restoration of Puget Sound Rivers. University of Washington Press, Seattle.

Kondolf, G. M., Montgomery, D. R., Piégay, H., and Schmitt, L. 2003. Geomorphic classification of rivers and streams. Pages 171-204 in G. M. Kondolf and H. Piégay (eds.). Tools in Fluvial Geomorphology. John Wiley \& Sons, Chichester.

Nehlsen, W., J. E. Williams, and J. A. Lichatowich. 1991. Pacific salmon at the crossroads: Stocks at risk from California, Oregon, Idaho, and Washington. Fisheries 16(2): 4-21.

Montgomery, D. R. 2000. Coevolution of the Pacific salmon and Pacific Rim topography. Geology 28: 1107-1110.

Montgomery, D. R. 2003. King of Fish: The Thousand-Year Run of Salmon. Westview Press, Boulder.
Montgomery, D. R., G. Pess, E. M. Beamer, and T. P. Quinn. 1999. Channel type and salmonid spawning distributions and abundance. Canadian Journal of Fisheries and Aquatic Sciences 56: 377-387.

Pess, G. R., D. R. Montgomery, R. E. Bilby, A. E. Steel, B. E. Feist, and H. M. Greenberg. 2002. Landscape characteristics, land use, and coho salmon (Oncorhynchus kisutch) abundance, Snohomish River, Washington State, USA. Canadian Journal of Fisheries and Aquatic Sciences 59: 613-623.

Rosenfeld, J., M. Porter, and E. Parkinson. 2000. Habitat factors affecting the abundance and distribution of juvenile cutthroat trout (Oncorhynchus clarki) and coho salmon (Oncorhynchus kisutch). Canadian Journal of Fisheries and Aquatic Sciences 57: 766-774. 